DOI: 10.46340/eppd.2020.7.5.18

Andrii Makarenko

ORCID ID: https://orcid.org/0000-0002-2930-349X

Institute of Public Administration and Research in Civil Protection, Kyiv, Ukraine

\title{
CURRENT STATE OF ADMINISTRATION OF PREHOSPITAL HELP IN EMERGENCY CONDITIONS OF THE PEACETIME IN UKRAINE
}

\author{
Андрій Макаренко \\ Інститут державного управління та наукових досліджень з цивільного захисту, \\ Київ, Україна
}

\section{СУЧАСНИЙ СТАН АДМІНІСТРУВАННЯ НАДАННЯМ ДОМЕДИЧНОЇ ДОПОМОГИ В УМОВАХ НАДЗВИЧАЙНИХ СИТУАЦІЙ МИРНОГО ЧАСУ В УКРАЇНI}

The purpose of the article is to study the ability to provide prehospital help in a state of emergency as casualties are part of the life of each of us. And the prehospital help is the complex of urgent measures for saving the life and health of the casualty. According to the requirements of health care, it is necessary that prehospital help is properly provided to each family, school, and every enterprise, as injuries are observed everywhere, and their consequences adversely affect our society. The human's chances of being saved in case of an emergency or heart attack and minimizing negative health effects depend on the early start of the help, so providing the prehospital help procedures is necessary for survival.

Keywords: emergencies, prehospital help, training, rescuer, practical experience.

Згідно зданими ВОО3, майже третина постраждалих під час катастроф мирного часу вимагають надання домедичної допомоги за життєвими показниками. За тими ж даними, кожен п'ятий з числа загиблих на місці події міг би бути врятованим, в разі отримання першої медичної допомоги, що була своєчасно та правильно наданою. Ушкодження, що отримані під час таких катастроф, характеризуються значною кількістю множинних і поєднаних травм, комбінованих ушкоджень, що супроводжуються травматичним i опіковим шоком, гострою крововтратою, асфіксією, синдромом тривалого стиснення. Такі пошкодження нерідко призводять до розвитку синдрому взаємного обтяження та часто супроводжуються психогенними реакціями. Всі ці фактори значно ускладнюють надання їм медичної допомоги. Із зазначеного стає зрозумілою величезна важливість надання домедичної допомоги та відповідальність, яка лягає на рятувальників та інших осіб, які перебувають безпосередньо на місці катастрофи ${ }^{1}$.

В Україні питанням удосконалення підготовки осіб, які не мають медичної освіти, але за своїми службовими обов'язками повинні надавати домедичну допомогу, та адаптації навчальнотренувальних програм до міжнародних стандартів надання невідкладної медичної допомоги присвячена ціла низка законодавчо-правових норм, зокрема, стаття 12 Закону України від 05.07.2012 p 5081-VI²; Постанова Кабінету Міністрів України від 21.11.2012 року № $1115^{3}$,

\footnotetext{
${ }^{1}$ Халмурадов, Б. Д., Волянський, П. Б. (2016). Медицина надзвичайних ситуацій. Київ: Центр учбової літератури.

2 Закон про екстрену медичну допомогу, 2012 (Верховна Рада України). Офічійний сайт Верховної Ради України <https://zakon.rada.gov.ua/laws/show/5081-17> (2019, грудень, 19).

${ }^{3}$ Постанова про затвердження порядку підготовки та підвищення кваліфікачії осіб, які зобов 'язані надавати домедичну допомогу, 2012 (Кабінет Міністрів України). Офіиійний сайт Кабінету Міністрів України $<$ https://www.kmu.gov.ua/npas/245849999> (2019, грудень, 19).
} 
Наказ МОЗ України від 02.03.2009 р. № 132'; Наказ МО3 України від 29.03.2017 р. № $346^{2}$. Також цим питанням присвячені дослідження: Gunn S.W.A, Stordeur K., Jackobs L., O. А. Акулової, П. Б. Волянського, С. О. Гур'єва, А. В. Терент'єва, І. В. Кочина, Т. Г. Карпінської, О. Л. Мірус, В. М. Фірмана, Н. М. Абашина, Б. Д. Халмурадова та інших.

Віддаючи належне результатам наукових пошуків вітчизняних та зарубіжних вчених у цій сфері, необхідно зазначити, що значна частка екстреної медичної допомоги (далі - ЕМД) та ДМД постраждалим в осередку надзвичайної ситуації (далі- $\mathrm{HC}$ ) мирного часу залишається недослідженою та невирішеною в повному обсязі. Зокрема невирішеним залишається питання здійснення підготовки з ДМД, як осіб, що приймають участь в ліквідації наслідків НС безпосередню в їі осередку, так і пересічних громадян, які внаслідок збігу життєвих обставин виявляються змушені таку допомогу надавати.

Метою статті $\epsilon$ вивчення шляхів оптимізації системи навчання 3 домедичної допомоги, в першу чергу, пересічних громадян, які мають необхідність діяти в складних умовах сьогодення, що характеризується, зокрема, наявністю фактично не об'явленої війни, а саме, дедалі частіших проявів тероризму та інших екстремальних обставин, в яких громадяни повинні вміти зберегти життя своїм рідним та близьким, надавши їм своєчасну та адекватну ДМД.

Зазначимо, що показники летальності будь-якої НС обумовлені, зокрема, медико-тактичними характеристиками такої надзвичайної події. Такі характеристики впливають на ймовірний ризик загибелі та травмування людей, що залежить від впливу різноманітних чинників при типових $\mathrm{HC}^{3}$. Дослідження та врахування наведеного фактору зможе істотно підвищити ефективність і обгрунтованість управлінських рішень під час надання домедичної допомоги в НС, що швидко змінюються.

Відомо, що перша допомога - це прості доцільні заходи для порятунку здоров'я і життя травмованих людей, надання яких має бути природною частиною нашого життя та обов'язком кожної людини.

Зауважимо, що в історії першої допомоги знаменним є 1859 рік, коли швейцарець Анрі Дюнан запропонував створити міжнародну організацію, головним завданням якої стало би надання першої допомоги пораненим у військових умовах. Саме завдяки цій ініціативі у 1864 році виникла така організація, як Червоний Хрест ${ }^{4}$.

Нині Червоний Хрест - це велика міжнародна організація, що об'єднує більше ста п’ятдесяти мільйонів членів. Її діяльність, що базується на наукових основах, широко розвинена майже у всьому світі ${ }^{5}$.

Ще однією визначною постаттю в сфері розвитку надання першої медичної допомоги ми можемо назвати російського хірурга М. Пирогова, який в 1853 р. під час кримської війни ввів цілеспрямовану обробку ран в польових умовах.

Початком запровадження в Україні дієвого законодавчого механізму надання першої медичної допомоги постраждалим внаслідок надзвичайних ситуацій можна вважати прийняття постанови Кабінету Міністрів України від 05.11.2007 p. № $1290^{6}$, де передбачено створення принципово нової для України системи підготовки i перепідготовки з питань надання домедичної допомоги рятувальниками i працівниками, професійні обов'язки яких пов'язані з експлуатацією автомобільного, залізничного, водного та повітряного транспорту та військовослужбовців. Після вищезгаданої постанови було прийнято цілу низку законодавчих актів, що деталізували питання надання ДМД та навчання відповідних категорій.

\footnotetext{
${ }^{1}$ Наказ про організацію навчання окремих категорій немедичних прачівників навичкам надання пермої невідкладної медичної допомоги, 2009 (Міністерство охорони здоров'я України). Офіційний сайт Верховної Ради Украӥни <http://zakon.rada.gov.ua/laws/show/z0445-09/ed20130325> (2019, грудень, 19).

${ }^{2}$ Наказ про затвердження загальних вимог щзодо проведення медичного сортування постраждалих $i$ хворих та форм медичної документаиії, 2017 (Міністерство охорони здоров'я України). Офіиіииний сайт Верховної Ради Украӥни <http://zakon.rada.gov.ua/laws/show/z0884-12> (2019, грудень, 19).

${ }^{3}$ Халмурадов, Б. Д., Волянський, П. Б. (2016). Медицина надзвичайних ситуацій. Київ: Центр учбової літератури.

4 Товариство Червоного Хреста України (2020). Історія створення Товариства Червоного Хреста

$<$ https://redcross.org.ua/rfl/history/> (2020, червень, 12).

${ }^{5}$ Международный Комитет Красного Креста (1997). Женевские конвенции и дополнительные протоколь к ним. Москва: Инфра-М.

${ }^{6}$ Постанова про затвердження Державної програми створення єдиної системи надання екстреної медичної допомоги, 2007 (Кабінет Міністрів України). Офіційний сайт Кабінету Міністрів України.

$<$ https://www.kmu.gov.ua/npas/96548251> (2019, грудень, 19).
} 
Верховною Радою України від 26.08.2011 р. № 9074 прийнято Закон України від 13.03.2012 p. № 4499-VI ${ }^{1}$, яким передбачено створення в Україні системи ЕМД за єдиним телефонним номером «112», що мало забезпечити оптимізацію надання допомоги, в тому числі медичної, у ситуаціях, які загрожують здоров'ю, життю, майну, навколишньому природному середовищу, громадському порядку тощо. Прийняття Закону має велике значення для інформаційного удосконалення функціональних підсистем Державної системи реагування на НС техногенного і природного характеру та їх оперативної інформаційної взаємодії. Оскільки ситуація, коли всі аварійно рятувальні служби є розрізненими та мають свої окремі телефонні номери (101, 102, 103 тощо) створює труднощі як населенню, так і медичним працівникам екстреної медичної допомоги (далі- ЕМД), які часто прибувають на місце події без супроводу відповідних оперативно-рятувальних служб і повинні виконувати не притаманні їм дії: діставати постраждалих з-під завалів, з пошкоджених автомобілів, забезпечувати оточення та охорону місця НС тощо. На теперішній час в Україні завершуються роботи зі створення єдиних чергово-диспетчерських служб, в межах яких служба ЕМД, особливо територіальні центри ЕМД та МК як безпосередні виконавці, повинні будуть брати активну участь у реалізації положень вищевказаного законодавчого акту.

Важливим кроком у нормативно-правовій регламентації ЕМД в умовах НС стало видання наказу МОЗ України від 18.05.2012 p. № $366^{2}$. Підкреслимо, що медичне сортування $\epsilon$ надважливим компонентом технології ЕМД в умовах НС і полягає у розподілі постраждалих осіб на певні групи за принципом їх потреби в однотипних лікувально-профілактичних та евакуаційних заходах, що залежать від медичних показань і конкретних обставин НС. У повсякденних умовах працівники системи ЕМД надають таку допомогу поодиноким постраждалим особам. При НС з великою кількістю постраждалих та диспропорцією між кількістю постраждалих, тяжкістю отриманих ними пошкоджень та численністю медичних сил і засобів завжди важко прийняти правильне рішення щодо визначення пріоритетних груп у наданні їм ЕМД. Наказ МОЗ України від 18.05.2012 p. № $366^{3}$ чітко регламентує загальні вимоги, етапи проведення медичного сортування, облікову форму медичної документації та інструкцію щодо її заповнення. Чітке дотримання положень цього наказу дасть змогу зберегти життя значної кількості постраждалих і попередити розвиток можливих ускладнень.

Згідно з сучасними дослідженнями, статистично значуще зростання показників виживання серед пацієнтів екстреної медичної допомоги досягається лише у разі, якщо початок надання ДМД відбувається не пізніше ніж через 4 хвилини після настання екстреної ситуації.

Очевидно, що настільки рання ДМД практично завжди може бути надана лише безпосередніми свідками події, від яких залежить ефективність такої першої допомоги, а також забезпечення базової підтримки життя постраждалих осіб. Звичайно, такі особи не можуть замінити професійних медичних працівників, але вони можуть допомогти підтримати життя до прибуття професіоналів.

Можемо навести наступний приклад. Медична діяльність на Заході суворо регламентована й підпорядкована виконанню протоколів медичної допомоги. 3 метою об'єднання зусиль країн світу для вдосконалення системи надання екстреної медичної допомоги (ЕМД) при катастрофах вперше в 1975 р. у Женеві було організовано Міжнародне суспільство медицини катастроф. У 1976 р. створено «Клуб Майнца» - Міжнародного товариства з невідкладної медицини, який у 1983 році був трансформований у Всесвітню асоціацію невідкладної медицини та медицини катастроф (WAEDM), a 31986 р. в Сан-Маріно діє Європейський науково-дослідний центр з медицини катастроф $\phi^{4,5,6}$.

\footnotetext{
1 Закон про систему екстреної допомоги населенню за єдиним телефонним номером 112, 2012 (Верховна Рада України). Офіиійний сайт Верховної Ради України. <http://zakon.rada.gov.ua/cgi-bin/laws/main.cgi?nreg=4499-17> (2019, грудень, 19).

${ }^{2}$ Наказ про затвердження загальних вимог щуодо проведення медичного сортування постраждалих $і$ хворих та форм медичної документації, 2012 (Верховна Рада України). Офіціийний сайт Верховної Ради України. <http://zakon.rada.gov.ua/laws/show/z0884-12> (2019, грудень, 19).

${ }^{3}$ Наказ про затвердження загальних вимог щодо проведення медичного сортування постраждалих $i$ хворих та форм медичної документації, 2012 (Верховна Рада України). Офіційний сайт Верховної Ради України. <http://zakon.rada.gov.ua/laws/show/z0884-12> (2019, грудень, 19).

${ }^{4}$ Медицина здравоохранения (1986). Организащия медиџинской помощии при массовых катастрофах за рубежом: Обзорная информация. Москва.

${ }^{5}$ Рябов, Г. А., Семенов, В. Н., Руденко, М. И. и др. (1990). Организация и опыт проведения медицинской помощи при массовых катастрофах. Военно-медицинский журнал, 4, 46-49.

${ }^{6}$ Gunn, S. W. A. (1988). Medicine for disaster. London; Boston: Wright, 145-151.
} 
При цьому, не зважаючи на те, що на сьогодні в світі накопичено великий досвід надання ЕМД, аналіз зарубіжної літератури показує, що досі немає єдиної виробленої системи організації ЕМД при катастрофах. Але в усіх країнах основу медицини катастроф становить ефективна служба швидкої медичної допомоги (ШМД) ${ }^{1,2}$.

В Законі України від 05.07.2012 p. № 5081-VI³ визначено організаційно-правові засади забезпечення громадян України та інших осіб, які перебувають на її території, екстреною медичною допомогою, у тому числі, під час виникнення НС та ліквідації їх наслідків, а також засади створення, функціонування і розвитку системи ЕМД.

В Законі зазначено, що особами, які зобов'язані надавати домедичну допомогу людині у невідкладному стані, $є$ : рятувальники аварійно-рятувальних служб, працівники державної пожежної охорони, працівники органів та підрозділів поліції, фармацевтичні працівники, водії автомобільних транспортних засобів, провідники пасажирських вагонів, бортпровідники та інші особи, які не мають медичної освіти, але за своїми професійними чи службовими обов'язками повинні володіти практичними навичками надання такої допомоги.

Чинним Кримінальним кодексом України (ККУ), передбачена кримінальна відповідальність за ненадання допомоги особі, яка перебуває в небезпечному для життя стані, коли у особи була можливість надати таку допомогу, або неповідомлення про такий стан особи відповідним установам або особам, якщо це заподіяло тяжкі тілесні ушкодження або смерть (ст. 136 ККУ). Якщо ж особа сама поставила в небезпечний для життя стан іншу людину або в силу свого правового становища повинна була піклуватися про неї, кримінальна відповідальність настає відповідно до положень ст. 135 ККУ за залишення в небезпеці. Кожна з цих статей передбачає різні санкції аж до позбавлення волі.

Кодексом цивільного захисту України від 02.10.2012 № 5403-VI ${ }^{41}$, який по суті є дорожньою картою не тільки для всієї системи ДСНС в цілому, а і для кожного працівника, деталізовані деякі аспекти навчання та надання домедичної допомоги рятувальниками.

Так, статтею 23 цього Кодексу визначено, що аварійно-рятувальні служби проводять пошук і рятування людей на уражених об'єктах і територіях, надання у можливих межах невідкладної, у тому числі медичної, допомоги особам, які перебувають у небезпечному для життя й здоров'я стані, на місці події та під час евакуації до лікувальних закладів. А стаття 110 зобов'язує рятувальників проходити періодичну підготовку з питань надання домедичної допомоги особам, постраждалим внаслідок надзвичайних ситуацій.

Підкреслимо, що відповідно до чинного законодавства України, певні категорії працівників, до функціональних обов'язків яких входить надання ДМД, отримують необхідні знання безкоштовно у спеціалізованих навчально-тренувальних підрозділах навчальних закладів (центрів). Але у повсякденному житті можуть виникати ситуації, коли поряд з особою, що знаходиться у невідкладному стані, немає нікого, хто б володів навичками надання ДМД.

Постановою Кабінету Міністрів України від 21 листопада 2012 p. N $1115^{5}$ зазначено, що підготовка та підвищення кваліфікації проводяться на базі вищих медичних і фармацевтичних навчальних закладів I-IV рівня акредитації незалежно від форми власності та підпорядкування, навчально-тренувальних відділів центрів екстреної медичної допомоги та медицини катастроф, навчально-тренувальних відділів Товариства Червоного Хреста, інших навчально-тренувальних підрозділів (далі - установи), які провадять діяльність відповідно до законодавства про освіту за програмами, затвердженими MO3 і погодженими з МOH України. Установи, на базі яких проводяться підготовка та підвищення кваліфікації, за рівнем матеріально-технічного забезпечення

\footnotetext{
${ }^{1}$ Медицина здравоохранения (1986). Организация медицинской помощчи при массовых катастрофах за рубежом: Обзорная информация. Москва.

${ }^{2}$ Борчук, Н. И. (2000). Опыт организации экстренной медицинской помощи при катастрофах за рубежом. Медицинские новости,7, 23-25.

3 Закон про екстрену медичну допомогу, 2012 (Верховна Рада України). Офіиійний сайт Верховної Ради України < https://zakon.rada.gov.ua/laws/show/5081-17> (2019, грудень, 19).

${ }^{4}$ Кодекс ичивільного захисту України, 2012 (Верховна Рада України). Офіційний сайт Верховної Ради Украӥни < https://zakon.rada.gov.ua/laws/show/5403-17> (2019, грудень, 19).

${ }^{5}$ Постанова Кабінету Міністрів України про затвердження порядку підготовки та підвищення кваліфікації осіб, які зобов'язані надавати домедичну допомогу, 2012 (Кабінет Міністрів України). Офіиійний сайт Кабінету Міністрів Украӥни < https://www.kmu.gov.ua/npas/245849999> (2019, грудень, 19).
} 
і підготовки викладачів повинні відповідати вимогам, що установлені МОН України. Відповідальним за наукове та методологічне забезпечення підготовки та підвищення кваліфікації викладачів i викладачів-інструкторів установ $є$ Український науково-практичний центр екстреної медичної допомоги та медицини катастроф.

Підготовка та підвищення кваліфікації проводяться за очною формою навчання та поділяються на перший, другий та третій рівень.

Строк підготовки та підвищення кваліфікації залежить від рівня знань і практичних навичок особи, що навчається. Вимоги щодо рівня знань і практичних навичок такої особи, а також відповідні строки підготовки та підвищення кваліфікації затверджуються МО3.

Також цією постановою затверджено зразок посвідчення про підготовку з надання домедичної допомоги.

У пункті 9 наведеної постанови визначено, що підготовка та підвищення кваліфікації з надання домедичної допомоги здійснюється установами на підставі договорів, які укладаються з відповідними органами виконавчої влади, підприємствами (установами, організаціями), а порядок здійснення та розмір оплати за проведення підготовки та підвищення кваліфікації встановлюються МОЗ за погодженням з Мінфіном.

Світовий досвід свідчить про те, що для забезпечення своєчасності надання невідкладної ДМД необхідно здійснювати широке залучати до надання ДМД немедичних працівників, які пройшли відповідне навчання. Вирішення цієї проблеми в Україні можливе за умови виконання МОЗ постанови Кабінету Міністрів України від 21 листопада 2012 р. № $1115^{1}$ та проведення уніфікації (відповідність змісту та часу навчання) великої кількості навчальних програм з ДМД, які існують на теперішній момент.

Досить вдалим, на наш погляд, в цьому контексті є наказ МОЗ України від 29.03.2017 № 346 2 . Програми підготовки та відповідні програми підвищення кваліфікації розроблено з урахуванням основних вимог міжнародних програм: «Основи підтримки життя», «Перший на місці події», «Професійна підтримка життя». Вони поділені на I, II та III рівні Програми підготовки та підвищення кваліфікації рівнів (8, 48 та 120 астрономічних годин відповідно).

Програма підготовки І рівень (Домедична допомога при раптовій зупиниі серия та загрозливих життю станах). Тривалість навчання 8 годин. Програма відповідає стандартам, передбаченим вимогами міжнародної програми BLS (basic life support) - основи підтримки життя (базисна допомога): практичні прийоми надання екстреної медичної допомоги при порушеннях або зупинці дихання, серцево-судинних розладах.

Програма розрахована на немедичних працівників, професійна діяльність яких не передбачає ризику отримання травматичних пошкоджень, отруєнь: офісні працівники, працівники сфери послуг, викладачі тощо.

Програма підготовки II рівень (Перший на місиі подіі). Тривалість навчання 48 годин. Термін "Перший на місці події” означає перших осіб, що прибули на місце події як індивідуально, так і в складі груп (до появи професійних медичних працівників). Перший на місці події - це людина, що виконує базові маніпуляції для порятунку життя постраждалого 3 використанням мінімального набору обладнання або за його повної відсутності.

Головне завдання першого на місці події- якнайшвидше розпочати процес надання невідкладної медичної допомоги тим, хто цього потребує. Курс передбачає розгляд базових понять

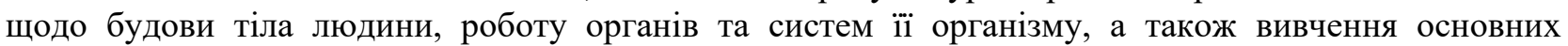
принципів і навичок, необхідних для оцінки стану постраждалого та надання домедичної допомоги в екстремальних умовах до прибуття бригади екстреної медичної допомоги (далі - бригада ЕМД).

Програма курсу грунтується на уніфікованих клінічних протоколах медичної допомоги та на алгоритмах міжнародних курсів Emergency Medical Responder, BLS, ITLS, PhTLS.

Курс розраховано на осіб, які зобов'язані надавати домедичну допомогу постраждалим у невідкладному стані, але не мають медичної освіти, а саме: співробітників Національної поліції

\footnotetext{
${ }^{1}$ Постанова про затвердження порядку підготовки та підвищення кваліфікації осіб, які зобов'язані надавати домедичну допомогу, 2012 (Кабінет Міністрів України). Офіиійний сайт Кабінету Міністрів Украӥни $<$ https://www.kmu.gov.ua/npas/245849999> (2019, грудень, 19).

${ }^{2}$ Наказ про удосконалення підготовки з надання домедичної допомоги осіб, які не мають медичної освіти, 2017 (Міністерство охорони здоров'я України). Медпросвіта <https://medprosvita.com.ua/nakaz-moz-ukrayini-vid2017-346-pro-udoskonalennya/> (2019, грудень, 19)
} 
України, працівників Державної служби України з надзвичайних ситуацій, фармацевтичних працівників, провідників пасажирських вагонів, бортпровідників та інших осіб, які за своїми службовими обов'язками повинні володіти практичними навичками надання домедичної допомоги.

Програма підготовки III рівень (Професійна підтримка життя). Тривалість навчання 120 годин. Програма відповідає вимогам міжнародної програми ALS - «Професійна підтримка життя» (розширені дії з надання першої допомоги). Метою навчання $є$ засвоєння розширених практичних умінь з надання першої допомоги при порушеннях або зупинці дихання, серцевосудинних порушеннях, зупинці серця, значній кровотечі, пошкодженнях голови та хребта, термічних ураженнях, гострих отруєннях, екстрених пологах.

Завданням програми $є$ одержання теоретичних медичних знань та практичних навичок надання першої допомоги дорослим і дітям в екстремальних ситуаціях як самостійно, так і під керівництвом працівника з медичною освітою. Програма розрахована на водіїв спеціального санітарного автотранспорту.

В проекті Закону України «Про внесення змін до деяких законів України щодо удосконалення надання першої допомоги» пропонується замінити термін «Домедична допомога» на термін «Перша допомога» ${ }^{1}$.

Перша допомога - невідкладні дії та організаційні заходи, спрямовані на врятування та збереження життя людини у невідкладному стані та мінімізацію наслідків впливу такого стану на ії здоров'я, що здійснюються на

місці події громадянами України, іноземцями та особами без громадянства, які не мають медичної освіти, а також особами, які за своїми службовими обов'язками повинні володіти основними практичними навичками з рятування та збереження життя людини, яка перебуває у невідкладному стані, та відповідно до закону зобов'язані здійснювати такі дії та заходи.

Обгрунтованим вважаємо наступну редакцію статті 12-1 «Про звільнення від юридичної відповідальності», а саме: особи, зазначені в частині першій статті 12 цього Закону, а також громадяни України, іноземці та особи без громадянства, які з власної волі і без очікування грошової винагороди надають першу допомогу на місці події за межами закладу охорони здоров'я або в будьякому іншому місці, в якому є необхідні медичні вироби, особі, яка перебуває у невідкладному стані, не несуть відповідальності за тілесні ушкодження, ймовірно отримані такою особою, або відповідальність за смерть особи, яка ймовірно сталася внаслідок дій або бездіяльності під час надання такої першої допомоги, за винятком, коли встановлено, що такі ушкодження або смерть були наслідком умислу або злочинної недбалості з боку особи, яка надає таку першу допомогу.

Враховуючи необхідність упорядкування та стандартизації навчання $з$ домедичної допомоги в системі ДСНС України, Службою було видано Наказ від 30.03.2018 p. № 206 «Про організацію підготовки та підвищення кваліфікації з надання домедичної допомоги в системі ДСНС» ${ }^{2}$, відповідно до чого Інститутом державного управління усфері цивільного захисту було розроблено та затверджено встановленим порядком навчальну програму II рівня підготовки з надання домедичної допомоги (Курс домедичної підготовки «Перший на місці події»), яка розрахована на 64 навчальні години та розіслана до навчальних закладів (підрозділів), що здійснюють підготовку та підвищення кваліфікації з надання домедичної допомоги. Програма курсу грунтується на уніфікованих клінічних протоколах медичної допомоги та на алгоритмах міжнародних курсів Emergency Medical Responder, BLS, ITLS, PhTLS.

В контексті цього Наказу забезпечено надання організаційно-методичної допомоги з питань проведення навчання з надання домедичної допомоги закладам вищої освіти ДСНС, професійнотехнічним навчальним закладам ДСНС та формуванням центрального підпорядкування, на базі яких здійснюється підготовка та підвищення кваліфікації осіб рядового і начальницького складу служби цивільного захисту, працівників органів та підрозділів ДСНС і основних працівників державних аварійно-рятувальних служб (загонів) сфери управління ДСНС, що дало змогу запровадити єдину систему навчання домедичній допомозі.

\footnotetext{
${ }^{1}$ Проект Закону Украӥни про внесення змін до деяких законів України щзодо удосконалення надання першої допомоги, 2019 (Верховна Рада України). Офіційний сайт Верховної ради України

$<$ http://w1.c1.rada.gov.ua/pls/zweb2/webproc4_1?id=\&pf3511=65250> (2019, грудень, 19).

${ }^{2}$ Наказ про організацію підготовки та підвищення кваліфікації з надання домедичної допомоги в системі ДСНС, 2018 (Державна служба України з надзвичайних ситуацій). Офіиійний сайт ДСНС України <https://www.dsns.gov.ua/ua/Nakazi/75771.html> (2020, червень, 14).
} 
Починаючи з вересня 2017 року, в контексті вказаної програми та з урахуванням вимог вищенаведеного наказу, в Інституті державного управління у сфері цивільного захисту відбувається навчання рятувальників з домедичної допомоги. Це навчання здійснюється досвідченим викладацьким складом, що пройшов підготовку на базі Державного закладу «Український науковопрактичний центр екстреної медичної допомоги та медицини катастроф» МОЗ України, Товариства Червоного Хреста України.

3 даної статті стає зрозумілим, що своєчасне та правильне надання домедичної допомоги $є$ запорукою порятунку життя та здоров'я постраждалого. Прості та доцільні заходи для порятунку травмованої людини повинні бути природною частиною життя та обов'язком кожного громадянина. Кожна людина повинна знати та вміти надавати домедичну допомогу, щоб у разі настання нещасного випадку життя максимальної кількості постраждалих осіб було врятовано, а негативні наслідки для їх здоров'я - мінімізовані. Якщо ми впевнені, що можемо надати домедичну допомогу, ми знаємо, що в разі необхідності врятують і нас.

Подальшими напрямами дослідження проблем ДМД вважаємо вивчення шляхів удосконалення медичного реагування в зоні надзвичайної ситуації.

\section{References:}

1. Gunn, S. W. A. (1988). Medicine for disaster. London; Boston: Wright. [in English].

2. Borchuk, N. I. (2000). Opyt organizatsii ekstrennoy meditsinskoy pomoshchi pri katastrofakh za rubezhom [Experience in organizing emergency medical care in case of accidents abroad]. Meditsinskiye novosti [Medical news],7, 23-25. [in Russian].

3. Zakon pro ekstrenu medychnu dopomohu, 2012 (Verkhovna Rada Ukrayiny) [Law on Emergency Medical Care, 2012 (Verkhovna Rada of Ukraine)]. Ofitsiynyy sayt Verkhovnoyi Rady Ukrayiny [Official site of the Verkhovna Rada of Ukraine] <https://zakon.rada.gov.ua/laws/show/5081-17> (2019, December, 19). [in Ukrainian].

4. Zakon pro ekstrenu medychnu dopomohu, 2012 (Verkhovna Rada Ukrayiny) [Law on Emergency Medical Care, 2012 (Verkhovna Rada of Ukraine)]. Ofitsiynyy sayt Verkhovnoyi Rady Ukrayiny [Official site of the Verkhovna Rada of Ukraine] <https://zakon.rada.gov.ua/laws/show/5081-17> (2019, December, 19). [in Ukrainian].

5. Zakon pro systemu ekstrenoyi dopomohy naselennyu za yedynym telefonnym nomerom 112, 2012 (Verkhovna Rada Ukrayiny) [Law on the system of emergency assistance to the population by a single telephone number 112, 2012 (Verkhovna Rada of Ukraine)]. Ofitsiynyy sayt Verkhovnoyi Rady Ukrayiny [Official site of the Verkhovna Rada of Ukraine] <http://zakon.rada.gov.ua/cgi-bin/laws/main.cgi?nreg=4499-17> (2019, December, 19). [in Ukrainian].

6. Kodeks tsyvilnoho zakhystu Ukrayiny, 2012 (Verkhovna Rada Ukrayiny) [Code of Civil Protection of Ukraine, 2012 (Verkhovna Rada of Ukraine)]. Ofitsiynyy sayt Verkhovnoyi Rady Ukrayiny [Official site of the Verkhovna Rada of Ukraine] <https://zakon.rada.gov.ua/laws/show/5403-17> (2019, December, 19). [in Ukrainian].

7. Meditsina zdravookhraneniya (1986) [Healthcare Medicine (1986)]. Organizatsiya meditsinskoy pomoshchi pri massovykh katastrofakh za rubezhom: Obzornaya informatsiya [Organization of medical care in case of mass disasters abroad: Survey information]. Moscow. [in Russian].

8. Mezhdunarodnyy Komitet Krasnogo Kresta (1997) [International Committee of the Red Cross (1997)]. Zhenevskiye konventsii i dopolnitelnyye protokoly $k$ nim [Geneva Conventions and Additional Protocols thereto]. Moscow: Infra-M [in Russian].

9. Nakaz pro zatverdzhennya zahalnykh vymoh shchodo provedennya medychnoho sortuvannya postrazhdalykh $i$ khvorykh ta form medychnoyi dokumentatsiyi, 2017 (Ministerstvo okhorony zdoroya Ukrayiny) [Order approving the general requirements for medical sorting of victims and patients and forms of medical documentation, 2017 (Ministry of Health of Ukraine)]. Ofitsiynyy sayt Verkhovnoyi Rady Ukrayiny [Official site of the Verkhovna Rada of Ukraine] <http://zakon.rada.gov.ua/laws/show/z0884-12> (2019, December, 19). [in Ukrainian].

10. Nakaz pro zatverdzhennya zahalnykh vymoh shchodo provedennya medychnoho sortuvannya postrazhdalykh $i$ khvorykh ta form medychnoyi dokumentatsiyi, 2012 (Verkhovna Rada Ukrayiny) [Order on approval of general requirements for medical sorting of victims and patients and forms of medical documentation, 2012 (Verkhovna Rada of Ukraine)]. Ofitsiynyy sayt Verkhovnoyi Rady Ukrayiny [Official site of the Verkhovna Rada of Ukraine] <http://zakon.rada.gov.ua/laws/show/z0884-12> (2019, December, 19). [in Ukrainian].

11. Nakaz pro zatverdzhennya zahalnykh vymoh shchodo provedennya medychnoho sortuvannya postrazhdalykh $i$ khvorykh ta form medychnoyi dokumentatsiyi, 2012 (Verkhovna Rada Ukrayiny) [Order on approval of general requirements for medical sorting of victims and patients and forms of medical documentation, 2012 (Verkhovna Rada of Ukraine)]. Ofitsiynyy sayt Verkhovnoyi Rady Ukrayiny [Official site of the Verkhovna Rada of Ukraine] <http://zakon.rada.gov.ua/laws/show/z0884-12> (2019, December, 19). [in Ukrainian].

12. Nakaz pro orhanizatsiyu navchannya okremykh katehoriy nemedychnykh pratsivnykiv navychkam nadannya pershoyi nevidkladnoyi medychnoyi dopomohy, 2009 (Ministerstvo okhorony zdorovya Ukrayiny) [Order on the organization of training of certain categories of non-medical workers in the skills of first aid, 2009 
(Ministry of Health of Ukraine).]. Ofitsiynyy sayt Verkhovnoyi Rady Ukrayiny [Official site of the Verkhovna Rada of Ukraine] <http://zakon.rada.gov.ua/laws/show/z0445-09/ed20130325> (2019, December, 19). [in Ukrainian].

13. Nakaz pro orhanizatsiyu pidhotovky ta pidvyshchennya kvalifikatsiyi z nadannya domedychnoyi dopomohy $v$ systemi DSNS, 2018 (Derzhavna sluzhba Ukrayiny z nadzvychaynykh sytuatsiy) [Order on the organization of training and retraining in the provision of home care in the SES, 2018 (State Service of Ukraine for Emergencies)]. Ofitsiynyy sayt DSNS Ukrayiny [Official site of the SES of Ukraine] <https://www.dsns.gov.ua/ua/Nakazi/75771.html> (2020, June, 14). [in Ukrainian].

14. Nakaz pro udoskonalennya pidhotovky z nadannya domedychnoyi dopomohy osib, yaki ne mayut medychnoyi osvity, 2017 (Ministerstvo okhorony zdorova Ukrayiny) [Order on improving the training in the provision of home care for persons without medical education, 2017 (Ministry of Health of Ukraine)]. Medprosvita [Medical education] <https://medprosvita.com.ua/nakaz-moz-ukrayini-vid-2017-346-pro-udoskonalennya/> (2019, December, 19). [in Ukrainian].

15. Postanova Kabinetu Ministriv Ukrayiny pro zatverdzhennya poryadku pidhotovky ta pidvyshchennya kvalifikatsiyi osib, yaki zobovazani nadavaty domedychnu dopomohu, 2012 (Kabinet Ministriv Ukrayiny) [Resolution of the Cabinet of Ministers of Ukraine on approval of the procedure for training and retraining of persons obliged to provide home care, 2012 (Cabinet of Ministers of Ukraine)]. Ofitsiynyy sayt Kabinetu Ministriv Ukrayiny [Official site of the Cabinet of Ministers of Ukraine] <https://www.kmu.gov.ua/npas/245849999> (2019, December, 19). [in Ukrainian].

16. Postanova pro zatverdzhennya Derzhavnoyi prohramy stvorennya yedynoyi systemy nadannya ekstrenoyi medychnoyi dopomohy, 2007 (Kabinet Ministriv Ukrayiny) [Resolution on approval of the State program for the creation of a unified system of emergency medical care, 2007 (Cabinet of Ministers of Ukraine)]. Ofitsiynyy sayt Kabinetu Ministriv Ukrayiny [Official site of the Cabinet of Ministers of Ukraine] <https://www.kmu.gov.ua/npas/96548251> (2019, December, 19). [in Ukrainian].

17. Postanova pro zatverdzhennya poryadku pidhotovky ta pidvyshchennya kvalifikatsiyi osib, yaki zobov'yazani nadavaty domedychnu dopomohu, 2012 (Kabinet Ministriv Ukrayiny) [Resolution on approval of the procedure for training and retraining of persons obliged to provide home care, 2012 (Cabinet of Ministers of Ukraine)]. Ofitsiynyy sayt Kabinetu Ministriv Ukrayiny [Official site of the Cabinet of Ministers of Ukraine] <https://www.kmu.gov.ua/npas/245849999> (2019, December, 19). [in Ukrainian].

18. Proekt Zakonu Ukrayiny pro vnesennya zmin do deyakykh zakoniv Ukrayiny shchodo udoskonalennya nadannya pershoyi dopomohy, 2019 (Verkhovna Rada Ukrayiny) [Draft Law of Ukraine on Amendments to Certain Laws of Ukraine on Improving First Aid, 2019 (Verkhovna Rada of Ukraine)]. Ofitsiynyy sayt Verkhovnoyi Rady Ukrayiny [Official site of the Verkhovna Rada of Ukraine] <http://w1.c1.rada.gov.ua/pls/zweb2/webproc4_1?id=\&pf3511=65250> (2019, December, 19). [in Ukrainian].

19. Ryabov, G. A., Semenov, V. N., Rudenko, M. I. and others (1990). Organizatsiya i opyt provedeniya meditsinskoy pomoshchi pri massovykh katastrofakh [Organization and experience of medical care in case of mass disasters]. Voyenno-meditsinskiy zhurnal [Military Medical Journal], 4, 46-49. [in Russian].

20. Tovarystvo Chervonoho Khresta Ukrayiny (2020) [Ukrainian Red Cross Society (2020)]. Istoriya stvorennya Tovarystva Chervonoho Khresta [History of the Red Cross Society] <https://redcross.org.ua/rfl/history/> (2020, June, 12). [in Ukrainian].

21. Khalmuradov, B. D., Volyanskyj, P. B. (2016). Medytsyna nadzvychaynykh sytuatsiy [Emergency medicine]. Kyiv: Center for Educational Literature. [in Ukrainian]. 